\title{
Actinidia (Mini Kiwi) Fruit Quality in Relation to Summer Cutting
}

\author{
Monika Figiel-Kroczyńska ${ }^{1}$, Ireneusz Ochmian ${ }^{1, * \mathbb{D}}$, Sabina Lachowicz ${ }^{2}{ }^{\mathbb{D}}$, Marcelina Krupa-Małkiewicz ${ }^{3}$, \\ Jacek Wróbel ${ }^{4}$ and Renata Gamrat ${ }^{5}$
}

1 Department of Horticulture, West Pomeranian University of Technology Szczecin, Słowackiego 17 Street, 71-434 Szczecin, Poland; monika.figiel-kroczynska@zut.edu.pl

2 Department of Fermentation and Cereals Technology, Wroclaw University of Environmental and Life Sciences, Chełmońskiego 37 Street, 51-630 Wrocław, Poland; sabina.lachowicz@upwr.edu.pl

3 Department of Genetic, Plant Breeding and Biotechnology, West Pomeranian University of Technology Szczecin, Słowackiego 17 Street, 71-434 Szczecin, Poland; mkrupa@zut.edu.pl

4 Department of Bioengineering, West Pomeranian University of Technology Szczecin, Słowackiego 17 Street, 71-434 Szczecin, Poland; jwrobel@zut.edu.pl

5 Department of Environmental Management, West Pomeranian University of Technology Szczecin, Słowackiego 17 Street, 71-434 Szczecin, Poland; renata.gamrat@zut.edu.pl

* Correspondence: iochmian@zut.edu.pl

check for updates

Citation: Figiel-Kroczyńska, M.; Ochmian, I.; Lachowicz, S.; Krupa-Małkiewicz, M.; Wróbel, J.; Gamrat, R. Actinidia (Mini Kiwi) Fruit Quality in Relation to Summer Cutting. Agronomy 2021, 11, 964. https://doi.org/10.3390/agronomy 11050964

Academic Editor: Salvatore Camposeo

Received: 19 April 2021

Accepted: 7 May 2021

Published: 12 May 2021

Publisher's Note: MDPI stays neutral with regard to jurisdictional claims in published maps and institutional affiliations.

Copyright: (c) 2021 by the authors. Licensee MDPI, Basel, Switzerland. This article is an open access article distributed under the terms and conditions of the Creative Commons Attribution (CC BY) license (https:/ / creativecommons.org/licenses/by/ $4.0 /)$.

\begin{abstract}
Recently, there has been a trend towards healthy food. Consumers are looking for products that have health-promoting properties in addition to their taste. Actinidia fruit, apart from being tasty, contains valuable macro and micronutrients, vitamins, polyphenols and pectins. Tested cultivar Sientiabrskaja belong to Actinidia arguta and cultivars Geneva, Issai and Ken's Red to A. kolomitka. They well tolerate conditions of moderate climate with negative temperatures in winter. To improve fruit quality, an additional summer pruning of the plants was performed at the time of ripening. After the second additional cutting of Actinidia shoots, an increase in the content of N, P and $\mathrm{K}$ in fruit was observed. The additional pruning also had a beneficial effect on the change in fruit color. The fruits were darker, especially in the cultivars Geneva and Ken's Red. This is related to the ripening of fruit and an increase in anthocyanin content. Additional summer pruning caused changes in the polyphenol content-the amount of phenolic acid and flavan-3 ols decreased, while the level of anthocyanins increased. The antioxidant capacity also increased as well as fruit size, dry matter, pectin and Soluble Solid Content (SSC) content. The acidity of the fruit also decreased which positively affects the taste of the fruit. The highest content of polyphenols and $L$-ascorbic acid was found in 'Sientiabrskaja' fruit; but the highest antioxidant activity (determined Free Radical Diphenylpicrylhydrazyl-DPPH•, ABTS•+ and Ferric Antioxidant Power-FRAP) was found in fruit with red skin coloring and anthocyanins-'Issai' and 'Ken's Red'.
\end{abstract}

Keywords: Actinidia arguta; A. kolomikta; colour; firmness; fruit quality; mineral content; polyphenols

\section{Introduction}

The Actinidia genus includes more than 60 species [1]. The most common species in the genus are Actinidia deliciosa and A. chinensis. Cultivars derived from A. eriantha, A. arguta, A. kolomikta and $A$. purpurea are also grown, which can also grow in colder regions due to their high frost resistance, down to $-30{ }^{\circ} \mathrm{C}$ [2]. Actinidia has shoot with very strong, intensive growth $(2-3 \mathrm{~m})$. As a result, to obtain high-quality fruit, the bushes must be skilfully pruned. More recently, the fruits of A. arguta and A. kolomikta have been commercially available under different names: kiwiberry, hardy kiwi, baby kiwi, grape kiwi, or mini kiwi [1,3]. Contrary to the most popular kiwi (A. chinensis), the fruits of these species are very sweet, aromatic, and small (grape-sized), with thin skin, devoid of mesquite and thus, they can be eaten whole without peeling [1,3]. The skin color is 
mostly green, but cultivars with red coloring are also available [3]. These fruits have strong antioxidant and anti-inflammatory effects, influenced by the biologically active substances they contain: vitamins C (150 mg/100 g) and E (4.6-5.3 mg/100 g), B vitamins, especially B8-myo-inositol (0.57-0.98 g/100 g), phenolics, and carotenoids [3-7]. A. arguta fruits are a better source of health-promoting compounds than popular kiwi fruit (A. deliciosa or A. chinensis) or fruits of other popular plant species [3]. Due to their high fiber content, consumption of $A$. arguta and A. kolomikta fruits normalizes intestinal peristalsis and helps to regulate metabolism [8]. Some hybrids, such as Issai, are particularly rich in vitamin C (up to $222 \mathrm{mg} / 100 \mathrm{~g}$ fresh weight (FW). Mini kiwi fruits can be considered the richest source of lutein among commercially available fruits [9]. The concept of oxygen free radicals and oxidative stress is currently commonplace. In the last two decades, there has been explosive interest in the role of oxygen free radicals, generally known as "reactive forms of oxygen" [10]. Many plants, mainly fruits and leaves, have such an effect. This is due to their unique chemical composition. Vitamin $C$ is an important nonenzymatic antioxidant substance. Its antioxidant activity cooperates mainly with vitamin $\mathrm{E}$ and carotenoids, as well as with antioxidant enzymes [10]. Both total polyphenols and vitamin $C$ are major components of the total antioxidant capacity of Actinidia fruit [11], and $\beta$-carotene has been shown to have pro-apoptotic effects in colon cancer and leukemia cells and to prevent cervical carcinogenesis [12,13]. DPPH $\bullet$, ABTS $\bullet+$, FRAP and ORAC tests are used to assess the antioxidant capacity of fresh fruits, vegetables and foods [10]. Thaipong et al. [4] showed that the FRAP technique was reproducible, simple and fast. It showed the highest correlation with both ascorbic acid and polyphenolic compounds.

The health-promoting value of kiwi fruit is highly dependent on climate, soil conditions and agrotechnology [14]. Agrochemical treatments also have a major impact on fruit storage [15]. Growth regulation is an important tool to maintain plant control and produce fruit of adequate quality [16]. Lack of adequate pruning during dormancy and summer results in the formation of a very dense crown, with fruits heavily shaded [17]. Systematic annual summer pruning helps to improve plant care (chemical treatment), inter-row care (mowing, fertilizing) and autumn fruit harvesting. Cutting also influences the better colouring of cultivars with blush. Fruits that are not properly lighted do not obtain the taste typical for the cultivar, soften prematurely and are not suitable for storage.

The high biological assay and frost resistance of $A$. arguta and A. kolomikta is causing increased interest in the cultivation of this plant among fruit growers in eastern and central Europe. They represent an alternative to kiwi fruit imported from countries with very warm climates. The experiment investigated whether additional shoot pruning (better fruit illumination) before harvesting effects changes in physicochemical properties of the fruit of cultivars derived from A. arguta and A. kolomikta.

\section{Materials and Methods}

\subsection{Characteristics of the Area of Research and Plant Material}

The experiment was conducted in the Department of Horticulture at West Pomeranian University of Technology in Szczecin in the 2016-2019 growing season, located in the northwestern part of Poland.

Four cultivars belonging to two species of the Actinidia family were studied in the experiment. The Actinidia arguta cultivar Sientiabrskaja and Actinidia kolomitka cultivars Geneva, Issai and Ken's Red belong to the species.

In the area of Szczecin and in the nearby northern region, minimal temperatures range from $-12{ }^{\circ} \mathrm{C}$ to $-15{ }^{\circ} \mathrm{C}$, which corresponds to values typical of zone $7 \mathrm{~B}$. The average temperature during the growing season (April-October) between 1951 and 2019 was $14.3^{\circ} \mathrm{C}$, and rainfall was approximately $350 \mathrm{~mm}$ [18].

Irrigation of the plantation was carried out annually using a permanently installed T-Tape drip irrigation line with a performance of $4.5 \mathrm{~L} / 1 \mathrm{~h} /$ per meter. The moisture content of the soil was maintained in the PF 1.8-2.1 range and was determined using contact tensiometers. 
The soil in the orchard was an agricultural soil with a natural profile developed from silt-loam with a $\mathrm{pH}$ of 6.9. The soil in which the shrubs grew was characterized by a high content of $\mathrm{P}(88 \mathrm{mg} / \mathrm{kg}), \mathrm{K}(145 \mathrm{mg} / \mathrm{kg})$ and $\mathrm{Mg}(66 \mathrm{mg} / \mathrm{kg})$. Every spring, nitrogen fertilization was used at a dose of $60 \mathrm{~kg} \mathrm{~N}$.

On all plants, the main pruning was carried out in winter, following a standard procedure. All shoots that crossed each other, thickened the plant or grew from below were removed. Each year cut back about one-quarter to one-third of the oldest laterals to a bud around $5 \mathrm{~cm}$ from the main stem.

\subsection{Weather Conditions during the Experiment}

Significant differences in weather were observed between 2016 and 2019. During this period, the weather was significantly different from that typical for this region. The average temperature from April to October was 0.1 to $1.5^{\circ} \mathrm{C}$ higher than the average temperature over a long period (1951-2012). In 1950-1989, the average temperature in the vegetation period was $13{ }^{\circ} \mathrm{C}$, but in some years, it did not even reach $12.5^{\circ} \mathrm{C}$. Between 1990 and 2006 , the average temperature in the growing season increased to $13.8^{\circ} \mathrm{C}$ but never fell below $13.5^{\circ} \mathrm{C}$. Precipitation varied over the years and in individual months. Extremely low precipitation occurred in 2018, especially during the fruit ripening period, in August and September (Table 1).

Table 1. Temperature and rainfall in the period from April to October (vegetation season) in 2016-2019 compared to the multiannual period (1951-2012) in Szczecin.

\begin{tabular}{ccccccccc}
\hline & \multicolumn{8}{c}{ Month } \\
\cline { 2 - 10 } & IV & V & VI & VII & VIII & IX & X & Mean \\
\hline Year & & \multicolumn{7}{c}{ average temperature $\left({ }^{\circ} \mathrm{C}\right)$} \\
\hline 2019 & 10.1 & 12.1 & 21.5 & 18.8 & 20.1 & 14.5 & 10.7 & 15.4 \\
2018 & 12.3 & 16.6 & 18.5 & 20.2 & 20.1 & 15.4 & 10.3 & 16.2 \\
2017 & 6.8 & 13.5 & 16.8 & 17.2 & 17.9 & 13.3 & 11.0 & 13.8 \\
2016 & 8.8 & 15.7 & 18.5 & 19.0 & 17.8 & 16.8 & 8.6 & 15.0 \\
\hline $1951-2012$ & 8.0 & 13.0 & 16.4 & 18.2 & 17.6 & 13.8 & 9.2 & 13.7 \\
\hline & & & & rainfall (mm) & & & Total \\
\hline 2019 & 10.7 & 68.7 & 70.8 & 23.5 & 41.8 & 39.4 & 46.1 & 301 \\
2018 & 26.8 & 22.5 & 15.0 & 92.8 & 21.4 & 16.3 & 20.2 & 215.0 \\
2016 & 42.3 & 99.2 & 118.1 & 182.4 & 145.4 & 31.6 & 95.1 & 714.1 \\
\hline $1951-2012$ & 20.2 & 18.9 & 69.0 & 50.1 & 47.8 & 18.3 & 55.3 & 279.6 \\
\hline
\end{tabular}

\subsection{Cutting Plants}

- One cut-control (control) On all plants a clear-cutting cut was made annually at the end of May and the beginning of June, according to a standard procedure. Shoots were cut a few leaves above the fruit, shoots without flowers and shoots growing too low were removed.

Eight bushes $\times$ three repetitions $\times$ four cultivars.

- Two cuts-A second (additional) cut was carried out between July and August. It was performed on half of the tested plants. Again, all shoots growing too low and shoots that grew too strong into the interrows or neighbouring plants, strong growing and thick shoots $>20 \mathrm{~mm}$, thickening the bush in the central part, were shortened. Pruning was to prevent the plants from becoming too dense.

Four shrubs $(50 \%) \times$ three repetitions $\times$ four cultivars. 


\subsection{Elemental Analysis}

The estimation of the content of minerals in dry weight plants was carried out in accordance with the Polish Standard [19]. All tests were performed each year in three replications. After harvest, we prepared a collective sample that was dried and ground.

The contents of elements in fruits were determined after mineralization: $\mathrm{N}, \mathrm{P}, \mathrm{K}, \mathrm{Ca}$ and $\mathrm{Mg}$ were measured after wet mineralization in $\mathrm{H}_{2} \mathrm{SO}_{4}(96 \%)$ and $\mathrm{HClO}_{4}(70 \%)$. The contents of $\mathrm{Cu}, \mathrm{Zn}, \mathrm{Mn}, \mathrm{Fe}$, and Se were determined after mineralization in $\mathrm{HNO}_{3}(65 \%)$ and $\mathrm{HClO}_{4}(70 \%)$ at a ratio of 3:1.

The total nitrogen concentration in plants was determined by the Kjeldahl distillation method using a Vapodest 30 (Gerhardt $\mathrm{GmbH}$, Germany). The K content was measured with atomic emission spectrometry, and the $\mathrm{Mg} \mathrm{Ca}, \mathrm{Cu}, \mathrm{Zn}, \mathrm{Mn}$ and $\mathrm{Fe}$ contents were measured with flame atomic absorption spectroscopy using iCE 3000 Series (Thermo Fisher Scientific, Waltham, MA, USA). Phosphorus (P) was assessed by the colorimetric method on a Specol 221 apparatus (Carl Zeiss, Jena, Germany) [20]. The Se concentration was measured fluorometrically using an RF-5001 PC Shimadzu spectrophotofluorometer. The excitation wavelength was $376 \mathrm{~nm}$, and the fluorescence emission wavelength was $518 \mathrm{~nm}$.

\subsection{General Fruits Parameters}

The firmness of fruits was measured on fresh berries immediately after harvest. Fruit diameter and firmness were measured with a FirmTech2 apparatus (BioWorks, Victor, NY, USA) of 100 randomly selected berries from three replicates. The result was expressed as a gram-force causing the fruit surface to bend $1 \mathrm{~mm}$. Every year, the measured fruit weight was measured (RADWAG WPX $4500 \pm 0.01 \mathrm{~g}$, Radom, Poland). The total Soluble Solid Content-SSC $\left({ }^{\circ} \mathrm{Bx}\right)$ in samples was measured at $20^{\circ} \mathrm{C}$ by digital refractometer (PAL-1, Atago, Japan). Acidity was determined by titration of aqueous extract with $0.1 \mathrm{~N} \mathrm{NaOH}$ to an end point with $\mathrm{pH} 8.1$ (Elmetron CX-732, Zabrze, Poland), according to the PN-90/A75101/04 [21] standard. Dry matter content was determined according to the relevant Polish Standard [21]. Dry weight content was measured after drying at $65^{\circ} \mathrm{C}$, with 3 repetitions of $250 \mathrm{~g}$ from each combination. The $L$-ascorbic acid and nitrate contents were measured with an RQflex 10 requantometer (Merck, Darmstadt, Germany) [22]. Pectin content was analyzed according to the Morris method described by Pijanowski et al. [23]. The content of provitamin A in fruits was determined by high-performance liquid chromatography with UV and fluorescence detection (Knauer K-1001 pump and Knauer K2001 UV detector-Knauer GmbH Berlin/Germany); Beckman ODS column (5 $\mu \mathrm{m})$, dimensions $150 \times 4.6 \mathrm{~mm}$, column temperature $25^{\circ} \mathrm{C}$ ) [24].

\subsection{Determination of Colour}

The pigment (color) of fruits was measured in transmission mode by a photocolorimetric (Konica Minolta CM-700d) method in a CIE $L^{*} a^{*} b^{*}$ system [25]. The diameter of the measurement hole was $3 \mathrm{~mm}$, the observer type was $10^{\circ}$ and the illuminant was D65. The value of $a^{*}$ indicates the surface color of fruits in the range from green $\left(-a^{*}\right)$ to red $\left(+a^{*}\right)$. The parameter $b^{*}$ describes the color in the range from yellow $\left(+b^{*}\right)$ to blue $\left(-b^{*}\right)$. The value of parameter $L^{*}$ means monochromaticity in the range from 0 (black) to 100 (white).

\subsection{Extraction Procedure and Identification of Phenolic Compounds, Antioxidant Activity}

The fruits were extracted with methanol acidified with $2.0 \%$ formic acid. Separation was conducted twice by incubation for 20 min under sonication (Sonic 6D, Polsonic, Warsaw, Poland). The sample was shaken several times. Subsequently, the suspension was centrifuged (MPW-251, MPW MED. INSTRUMENTS, Warsaw, Poland) at 19,000 $\times g$ for $10 \mathrm{~min}$. Prior to analysis, the supernatant was additionally purified with a Hydrophilic PTFE $0.20 \mu \mathrm{m}$ membrane (Millex Samplicity Filter, Merck, Darmstadt, Germany). All extractions were carried out in triplicate.

Analyses were performed according to the methodology of Oszmiański et al. [26]. In kiwiberry fruit extracts, polyphenol identification was executed using an ACQUITY 
Ultra Performance LC system appointed with a binary solvent manager, a photodiode array detector (Waters Corporation, Milford, MA, USA) and a G2 Q-TOF micro mass spectrometer (Waters, Manchester, UK) equipped with an electrospray ionization (ESI) source operating in both negative and positive modes.

Separations of individual polyphenols in kiwiberry fruit extracts were carried out using a UPLC BEH C18 column $(1.7 \mu \mathrm{m}, 2.1 \times 100 \mathrm{~mm}$, Waters Corporation, Milford, MA, USA) at $30^{\circ} \mathrm{C}$. The samples $(10 \mu \mathrm{L})$ were injected, and the elution was completed in $15 \mathrm{~min}$ with a sequence of linear gradients and isocratic flow rates of $0.45 \mathrm{~mL} \mathrm{~min}$. The mobile phase consisted of solvent A ( $2.0 \%$ formic acid, $v / v)$ and solvent B (100\% acetonitrile). The program began with isocratic elution with $99 \%$ solvent $A(0-1 \mathrm{~min})$, and then a linear gradient was used until $12 \mathrm{~min}$, lowering solvent A to $0 \%$; from 12.5 to $13.5 \mathrm{~min}$, the gradient returned to the initial composition $(99 \% \mathrm{~A})$, and then it was held constant to re-equilibrate the column. All measurements were repeated three times. The results were expressed as mg per $100 \mathrm{~g}$ of dry matter $(\mathrm{dm})$.

2,2'-azo-bis-3-ethylbenzothiazoline-6-sulfonic acid (ABTS•+) was used to observe the enzyme kinetics of assays Arnao et al. [27]. Additionally, DPPH• (1,1-diphenyl-2picrylhydrazyl) and the ferric reducing antioxidant property (FRAP) were also determined $[28,29]$. The antioxidant capacity was expressed as millimoles of Trolox per $100 \mathrm{~g}$ distilled water. ABTS + and FRAP assay measurements were carried out on a UV-2401 PC spectrophotometer. The determination was performed in three repetitions.

\subsection{Reagents}

$\mathrm{NaOH} 0.1 \mathrm{~N}, \mathrm{H}_{2} \mathrm{SO}_{4} 96 \% \mathrm{HClO}_{4} 70 \%$ and $\mathrm{HNO}_{3} 65 \%$ (ISO A.C.S. $99.90-99.99 \%$ ) were purchased from Chempur, Poland. Ethanol, formic acid, acetic acid, ABTS $\bullet+\left(2,2^{\prime}-\right.$ azinobis (3-ethylbenzothiazoline-6-sulfonic acid), DPPH• (1,1-diphenyl-2-picrylhydrazyl), Trolox (6-hydroxy-2,5,7,8-tetramethylchroman-2-carboxylic acid) were purchased from Sigma-Aldrich, Steinheim, Germany (ISO A.C.S. 99.999-99.9999\%). (-)-Epicatechin, (+)catechin, chlorogenic acid, neochlorogenic acid, cryptochlorogenic acid, procyanidin A2, procyanidin B2, $p$-coumaric acid, ferulic acid, caffeic acid, 4-caffeoylquinic, kampferol-3-Ogalactoside, quercetin-3-O-rutinoside, quercetin-3-O-galactoside, quercetin-3-O-glucoside, cyanidin-3-O-arabinoside, cyanidin-3-O-xyloside, cyanidin-3-O-galactoside and cyanidin-3$O$-glucoside were purchased from Extrasynthese (Lyon, France). Acetonitrile and methanol for ultra-performance liquid chromatography (UPLC; Gradient grade) and ascorbic acid were from Merck, Darmstadt, Germany (ISO A.C.S. 99.999-99.9999\%).

\subsection{Statistical Analysis}

All statistical analyses were performed using Statistica 13.5 (StatSoft Polska, Cracow, Poland). Nonparametric methods (Kruskal-Wallis test) were used if neither the homogeneity of variance nor the normality of distribution was established previously. Statistical significance of the differences between means was determined by testing the homogeneity of variance and normality of distribution, followed by ANOVA with Tukey's post hoc test. The significance was set at $p<0.05$.

\section{Results and Discussion}

\subsection{Mineral Compounds in Actinidia Fruits}

The study of the chemical composition of fruits considered food is important from a nutritional and toxicological point of view. The mineral composition of kiwiberry is quite variable and depends on its genetic characteristics (cultivar) and growth conditions-soil, weather [3]. Mineral nutrients also have important functions in the human body. Agrotechnical treatments should increase the content of these nutrients. The main components of Actinidia fruit were $\mathrm{K}, \mathrm{N}$ and, in smaller amounts, $\mathrm{P}, \mathrm{Ca}$ and $\mathrm{Mg}$ (Table 2). A different order for macronutrients and micronutrients for kiwiberry was presented by Latocha [3] $\mathrm{K}>\mathrm{Ca}$ $>\mathrm{P}>\mathrm{Mg}>\mathrm{Na}$. Regardless of the number of cuts the fruits of the Sientiabrskaja cultivar were rich in N, P, Zn and Mn while they had the least K and Ca. While Ken's Red cultivar 
contained the most K, Fe the least N, P, Cu and Se. The differences in the content of these elements were up to several hundred per cent-Mg, $\mathrm{Zn}, \mathrm{Cu}$ and Se (Tables 2 and 3).

Table 2. The contents of macronutrients in Actinidia fruits depending on the number of summer cuts.

\begin{tabular}{|c|c|c|c|c|c|c|}
\hline \multirow{2}{*}{$\begin{array}{l}\text { Compounds } \\
(\mathrm{g} / \mathrm{kg})\end{array}$} & \multicolumn{6}{|c|}{ Cultivar } \\
\hline & Summer Cuts & Sientiabrskaja & Genewa & Issai & Ken's Red & Mean \\
\hline \multirow{3}{*}{$\mathrm{N}$} & 1 cut-control & $9.88 \mathrm{f} *$ & $9.04 \mathrm{~d}$ & $8.15 c$ & $7.06 a$ & $8.53 \mathrm{~A}$ \\
\hline & 2 cuts & $10.23 \mathrm{~g}$ & $9.41 \mathrm{e}$ & $8.37 \mathrm{c}$ & $7.45 b$ & 8.87B \\
\hline & Mean & $10.06 \mathrm{D}$ & $9.23 \mathrm{C}$ & $8.26 \mathrm{~B}$ & $7.26 \mathrm{~A}$ & \\
\hline \multirow{3}{*}{$\mathrm{P}$} & 1 cut-control & $4.95 \mathrm{e}$ & $3.89 \mathrm{~b}$ & $4.34 \mathrm{~cd}$ & $3.11 \mathrm{a}$ & $4.07 \mathrm{~A}$ \\
\hline & 2 cuts & $5.11 \mathrm{e}$ & $4.20 c$ & $4.42 \mathrm{~d}$ & $3.64 b$ & 4.34B \\
\hline & Mean & $5.03 \mathrm{D}$ & $4.04 \mathrm{~B}$ & $4.38 \mathrm{C}$ & $3.37 \mathrm{~A}$ & \\
\hline \multirow{3}{*}{ K } & 1 cut-control & $14.21 \mathrm{a}$ & $17.23 d$ & $15.06 \mathrm{~b}$ & $17.60 \mathrm{e}$ & $16.03 \mathrm{~A}$ \\
\hline & 2 cuts & $15.18 b$ & $18.02 \mathrm{f}$ & $15.87 \mathrm{c}$ & $17.99 \mathrm{f}$ & 16.77B \\
\hline & Mean & $14.70 \mathrm{~A}$ & $17.63 \mathrm{C}$ & 15.47B & $17.80 \mathrm{C}$ & \\
\hline \multirow{3}{*}{$\mathrm{Ca}$} & 1 cut-control & $2.79 a$ & $4.58 \mathrm{e}$ & $4.11 \mathrm{~d}$ & $3.45 c$ & $3.73 \mathrm{~A}$ \\
\hline & 2 cuts & $2.83 a$ & $4.22 \mathrm{~d}$ & $4.87 \mathrm{f}$ & $3.03 b$ & $3.74 \mathrm{~A}$ \\
\hline & mean & $2.81 \mathrm{~A}$ & $4.40 \mathrm{C}$ & $4.49 \mathrm{C}$ & $3.24 \mathrm{~B}$ & \\
\hline \multirow{3}{*}{$\mathrm{Mg}$} & 1 cut-control & $0.94 \mathrm{~d}$ & $0.57 \mathrm{~b}$ & $1.04 \mathrm{e}$ & $0.83 c$ & $0.85 \mathrm{~A}$ \\
\hline & 2 cuts & $0.88 \mathrm{~cd}$ & $0.49 a$ & $1.23 \mathrm{f}$ & $0.81 \mathrm{c}$ & $0.85 \mathrm{~A}$ \\
\hline & mean & $0.91 B C$ & $0.53 \mathrm{~A}$ & $1.13 \mathrm{C}$ & $0.82 \mathrm{~B}$ & \\
\hline
\end{tabular}

* Means followed by the same letter do not differ significantly at $p=0.05$ according to Tukey multiple range; lower-case letters indicate interaction and capital letters the main factors.

Table 3. The contents of micronutrients in the leaves and fruits of Actinidia.

\begin{tabular}{|c|c|c|c|c|c|c|}
\hline \multirow{2}{*}{$\begin{array}{l}\text { Compounds } \\
\text { (mg/kg) }\end{array}$} & \multicolumn{6}{|c|}{ Cultivar } \\
\hline & Summer Cuts & Sientiabrskaja & Genewa & Issai & Ken's Red & Mean \\
\hline \multirow{3}{*}{$\mathrm{Fe}$} & 1 cut-control & $14.07 \mathrm{~b}$ * & $12.37 \mathrm{a}$ & $15.71 \mathrm{c}$ & $21.44 \mathrm{e}$ & $15.90 \mathrm{~A}$ \\
\hline & 2 cuts & $14.22 \mathrm{~b}$ & $12.52 \mathrm{a}$ & $15.88 \mathrm{c}$ & $21.06 \mathrm{~d}$ & $15.92 \mathrm{~A}$ \\
\hline & mean & 14.15B & $12.45 \mathrm{~A}$ & $15.80 \mathrm{C}$ & 21.25D & \\
\hline \multirow{3}{*}{$\mathrm{Zn}$} & 1 cut-control & $11.89 \mathrm{~h}$ & $5.44 \mathrm{a}$ & $6.12 d$ & $6.88 \mathrm{f}$ & $7.58 \mathrm{~A}$ \\
\hline & 2 cuts & $11.05 \mathrm{~g}$ & $5.63 b$ & $5.91 \mathrm{c}$ & $6.36 \mathrm{e}$ & $7.24 \mathrm{~A}$ \\
\hline & mean & 11.47D & $5.54 \mathrm{~A}$ & $6.02 \mathrm{~B}$ & $6.62 \mathrm{C}$ & \\
\hline \multirow{3}{*}{$\mathrm{Mn}$} & 1 cut-control & $2.55 \mathrm{e}$ & $1.57 \mathrm{a}$ & $1.73 b$ & $2.11 \mathrm{c}$ & $1.99 \mathrm{~A}$ \\
\hline & 2 cuts & $2.34 \mathrm{~d}$ & $1.88 \mathrm{~b}$ & $1.52 \mathrm{a}$ & $2.40 \mathrm{~d}$ & $2.04 \mathrm{~A}$ \\
\hline & mean & $2.45 \mathrm{C}$ & $1.73 \mathrm{~A}$ & $1.63 \mathrm{~A}$ & $2.26 \mathrm{~B}$ & \\
\hline \multirow{3}{*}{$\mathrm{Cu}$} & 1 cut-control & $3.84 \mathrm{~b}$ & $4.50 \mathrm{e}$ & $4.02 \mathrm{c}$ & $1.62 \mathrm{a}$ & $3.50 \mathrm{~A}$ \\
\hline & 2 cuts & $3.79 b$ & $4.28 \mathrm{de}$ & $4.19 \mathrm{~d}$ & $1.72 \mathrm{a}$ & $3.50 \mathrm{~A}$ \\
\hline & Mean & $3.82 \mathrm{~B}$ & $4.39 \mathrm{D}$ & $4.11 \mathrm{C}$ & $1.67 \mathrm{~A}$ & \\
\hline \multirow{3}{*}{ Se } & 1 cut-control & $0.13 c$ & $0.23 \mathrm{~d}$ & $0.29 \mathrm{e}$ & $0.09 a$ & $0.19 \mathrm{~A}$ \\
\hline & 2 cuts & $0.11 b$ & $0.19 c$ & $0.31 \mathrm{f}$ & $0.08 \mathrm{a}$ & $0.17 \mathrm{~A}$ \\
\hline & mean & $0.12 B$ & $0.21 \mathrm{C}$ & $0.30 \mathrm{D}$ & $0.09 \mathrm{~A}$ & \\
\hline
\end{tabular}

${ }^{*}$ Means followed by the same letter do not differ significantly at $p=0.05$ according to Tukey multiple range; lower-case letters indicate interaction and capital letters the main factors.

Additional summer pruning in the majority of plants caused an increase in $\mathrm{N}, \mathrm{P}, \mathrm{K}$ but decreased Ca content. N and K content in the fruits of the cv. Sientiabrskaja did not differ significantly from the study of Bieniek [30], respectively 12.21 and $4.14 \mathrm{~g} / 100 \mathrm{~g}$. The Ca content also has an effect on the firmness of the fruit, and this relationship can be seen in the cultivar Sientiabrskaja, the fruits of which are the softest (Table 4). The Ca content of mini kiwi fruit is a cultivar characteristic. Usually in larger fruits the concentration of Ca is lower because they stop collecting it during growth [15,31]. The study conducted 
did not confirm this relationship and the direction of changes in Ca content, fruit size and firmness varied. Firmer mini kiwi fruit tolerate better storage in CA. However, there was no obvious influence of summer pruning on changes in the content of the analysed microelements in fruit. However, very large differences were found in the content of micronutrients in the fruits of the studied cultivars (Table 3). The greatest differences were found in selenium. In the fruits of Ken's Red cultivar, it was at the level of $0.09 \mathrm{mg} / 1000 \mathrm{~g}$, while Issai fruits contained selenium at as much as $0.3 \mathrm{mg} / 1000 \mathrm{~g}$. Mini kiwi fruit can be a good source of minerals and a supplement in the human diet. It has been established that the recommended daily allowance (RDA) should be 0.04-0.07 $\mathrm{mg} \mathrm{Se}, 2 \mathrm{mg} \mathrm{Cu}, 18 \mathrm{mg} \mathrm{Fe}$, $400 \mathrm{mg} \mathrm{Mg}, 2 \mathrm{mg} \mathrm{Mn}, 1000 \mathrm{mg}$ P, $15 \mathrm{mg} \mathrm{Zn}$ and [32,33].

Table 4. Color of fruits and the quality of Actinidia fruits.

\begin{tabular}{|c|c|c|c|c|c|c|c|}
\hline \multirow{2}{*}{\multicolumn{2}{|c|}{ Compounds }} & \multicolumn{6}{|c|}{ Cultivar } \\
\hline & & Summer Cuts & Sientiabrskaja & Genewa & Issai & Ken's Red & Mean \\
\hline \multirow{9}{*}{ 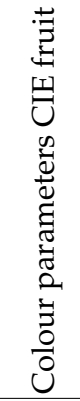 } & \multirow{3}{*}{$L^{*}$} & 1 cut-control & $50.6 f *$ & $42.5 \mathrm{~d}$ & $43.8 \mathrm{~d}$ & $29.1 b$ & $41.5 \mathrm{~A}$ \\
\hline & & 2 cuts & $48.5 \mathrm{e}$ & $42.0 \mathrm{~d}$ & $39.5 c$ & $25.9 a$ & $39.0 \mathrm{~A}$ \\
\hline & & mean & $49.5 \mathrm{C}$ & $42.2 \mathrm{~B}$ & $41.6 \mathrm{~B}$ & $27.5 \mathrm{~A}$ & \\
\hline & \multirow{3}{*}{$a^{*}$} & 1 cut-control & $-29.4 b$ & $18.4 \mathrm{c}$ & $-7.8 \mathrm{a}$ & $47.5 \mathrm{e}$ & $7.2 \mathrm{~A}$ \\
\hline & & 2 cuts & $-30.4 b$ & $24.6 \mathrm{~d}$ & $-7.0 \mathrm{a}$ & $51.8 f$ & $9.7 \mathrm{~B}$ \\
\hline & & mean & $-29.9 \mathrm{~A}$ & $21.5 \mathrm{C}$ & $-7.4 \mathrm{~B}$ & $49.6 \mathrm{D}$ & \\
\hline & \multirow{3}{*}{$b^{*}$} & 1 cut-control & $37.2 \mathrm{f}$ & $24.8 \mathrm{a}$ & $28.8 b$ & $31.6 \mathrm{~d}$ & $30.6 \mathrm{~A}$ \\
\hline & & 2 cuts & $34.6 \mathrm{e}$ & $28.9 b$ & $29.7 b$ & $30.8 \mathrm{~cd}$ & $31.0 \mathrm{~A}$ \\
\hline & & mean & $35.9 C$ & $26.8 \mathrm{~A}$ & 29.2B & $31.2 \mathrm{~B}$ & \\
\hline \multirow{3}{*}{\multicolumn{2}{|c|}{ Firmness (G/mm) }} & 1 cut-control & $112 b$ & $125 b$ & $144 \mathrm{~cd}$ & $155 d$ & $134 \mathrm{~A}$ \\
\hline & & 2 cuts & $98 a$ & $119 b$ & $140 c$ & $148 \mathrm{~cd}$ & $126 \mathrm{~A}$ \\
\hline & & mean & $105 \mathrm{~A}$ & $122 B$ & $142 \mathrm{C}$ & $151 C$ & \\
\hline \multirow{3}{*}{\multicolumn{2}{|c|}{ Weight of 100 fruits (g) }} & 1 cut-control & $616 c$ & $792 d$ & $519 a$ & $531 \mathrm{ab}$ & $615 \mathrm{~A}$ \\
\hline & & 2 cuts & $631 c$ & $788 \mathrm{~d}$ & $548 \mathrm{ab}$ & $557 \mathrm{~b}$ & $631 \mathrm{~A}$ \\
\hline & & mean & $624 \mathrm{~B}$ & $790 \mathrm{C}$ & 534A & $544 \mathrm{~A}$ & \\
\hline
\end{tabular}

* Means followed by the same letter do not differ significantly at $p=0.05$ according to Tukey multiple range; lower-case letters indicate interaction and capital letters the main factors.

Selenium is a component of selenoproteins, some of which have important enzymatic functions [34]. In the case of selenium, the recommended standard and the toxic dose to the body are very similar. If the concentration of this element is exceeded, so-called selenosis occurs, which can be symptomized by hair loss, mood changes, fatigue, weight loss, and a characteristic odor from the mouth, similar to that after eating garlic. With long-term selenosis, damage to the nervous system can occur and even death [35]. Selenium enters the food chain through plants, which take it up from the soil. Selenium deficiency has there-fore been identified in parts of the world characterized by low soil selenium content, such as the volcanic areas of Europe. In general, it was found that the fruit, especially the 'Issai', was rich in this element. The content was similar to some mushrooms, which are rich in this element [36]. They had a higher content than most vegetables but a lower content than nuts [37].

Other micronutrients are also essential for proper human functioning and health. Copper is involved in supporting cardiovascular health and glucose and cholesterol metabolism [38]. Copper is toxic to humans when the level in food products exceeds $20 \mathrm{mg} / 1000 \mathrm{~g}$. In humans, a deficiency is more unfavorable than an excess of copper, as it disturbs many processes. Iron is an essential micronutrient due to its high functionality. There are no standards defining the acceptable level of $\mathrm{Zn}$ in food products. In not very large amounts, it is necessary for the proper functioning of living organisms. According to SCF [39], it would be unwise to exceed the daily intake of $30 \mathrm{mg}$ in adults. The results indicate that on average, approximately $1 \mathrm{~kg}$ of fruit meets the daily human requirement 
for these nutrients, but the micronutrients are absorbed by humans only to a small extent. There is little chance of an overdose of $\mathrm{Cu}, \mathrm{Zn}, \mathrm{Mn}$ or Se from the consumption of mini kiwis. Instead, they are a tasty source of microelements that can supplement the human diet.

\subsection{Fruit Color and Quality in Actinidia Fruits}

The color of the skin of mini kiwi fruits and their flesh varies between cultivars [3]. The fruits of most cultivars are green, but there are also cultivars with a red blush and fruits with a brown-red color. Most consumers prefer red fruits, which seem to be tastier, sweeter. Significant differences in the colour of fruit of the studied cultivars and changes in their colour after additional summer pruning were found. The fruit of 'Sientiabrskaja' is definitely the greenest ( $\left.a^{*}-29.9\right)$ and the lightest $\left(L^{*} 49.5\right)$, while 'Ken's Red' is brown-black $\left(L^{*} 27.5, a^{*}+49.6\right)$, which is reflected in the botanical description of these cultivars. The lightest fruits were of the Sientiabrskaja cultivar (50.6 and 48.5), and the darkest were of the Ken's Red cultivar (25.9 and 29.1). After the second cutting the fruit darkened, on the cultivars Geneva and Ken's Red the blush became more red (increase in the value of the parameter $a^{*}$ and decrease in the value of $b^{*}$ ). This is a normal process as the fruit gradually ripens. The colour changes, or the more intense red colouring of the fruit, are also evidenced by changes in the amount of polyphenols, mainly an increase in anthocyanins. The high firmness of the fruit is an essential element for its transport and long-term storage. It affects the resistance to mechanical damage of the fruit. It is a characteristic of the cultivar but also depends on the size of the fruit [31]. A similar trend was observed during the period of this study. There was no significant effect of summer pruning on fruit firmness, except for the cultivar Sientiabrskaja. The fruits of the cultivars Ken's Red and Issai were the firmest. They also had the smallest fruits. The weight of 100 fruits of the studied cultivars ranged from 519 (Issai) to $792 \mathrm{~g}$ (Geneva) (Table 4). After the 2nd summer pruning, an increase in fruit weight and improvement of their flavour and health promoting properties were observed (Table 5). This may have resulted in better plant light and less competition for nutrients. Bieniek (2012) obtained lower or similar values for 'Sientiabrskaja' in individual years, 4.83-6.27 g. Leontowicz et al. [14] obtained average fruit masses of 6.8, 7.1 and $7.4 \mathrm{~g}$ for the three cultivars 'Ananasnaya', 'Weiki' and 'Bingo', respectively. These are similar values as were obtained for 'Sientiabrskaja' and 'Geneva' (Table 4).

Table 5. The quality, antioxidant capacity of Actinidia fruits.

\begin{tabular}{|c|c|c|c|c|c|c|}
\hline \multirow{2}{*}{ Compounds } & \multicolumn{6}{|c|}{ Cultivar } \\
\hline & Summer Cuts & Sientiabrskaja & Genewa & Issai & Ken's Red & Mean \\
\hline \multirow{3}{*}{$\begin{array}{l}\text { Soluble Solid Content-SSC } \\
\qquad\left({ }^{\circ} \mathrm{Bx}\right)\end{array}$} & 1 cut-control & $12.8 \mathrm{a} *$ & 13.0ab & $14.2 \mathrm{~cd}$ & $13.5 b$ & $13.4 \mathrm{~A}$ \\
\hline & 2 cuts & 13.3ab & $13.2 \mathrm{ab}$ & $14.4 d$ & $13.9 c$ & 13.7B \\
\hline & mean & $13.1 \mathrm{~A}$ & $13.1 \mathrm{~A}$ & $14.3 \mathrm{C}$ & $13.7 \mathrm{~B}$ & \\
\hline \multirow{3}{*}{$\begin{array}{l}\text { Dry weight } \\
(\mathrm{g} / 100 \mathrm{~g})\end{array}$} & 1 cut-control & $17.4 \mathrm{a}$ & $17.7 \mathrm{bc}$ & $18.6 \mathrm{~d}$ & $19.3 \mathrm{e}$ & $18.3 \mathrm{~A}$ \\
\hline & 2 cuts & $17.5 \mathrm{ab}$ & $17.9 \mathrm{c}$ & $18.8 \mathrm{~d}$ & $19.6 \mathrm{f}$ & $18.5 \mathrm{~A}$ \\
\hline & mean & $17.5 \mathrm{~A}$ & $17.8 \mathrm{~A}$ & 18.7B & $19.5 \mathrm{C}$ & \\
\hline \multirow{3}{*}{$\begin{array}{l}\text { Pectines } \\
(\mathrm{g} / 100 \mathrm{~g})\end{array}$} & 1 cut-control & $2.44 \mathrm{~d}$ & $2.22 b c$ & $2.25 b c$ & $1.98 \mathrm{a}$ & $2.22 \mathrm{~A}$ \\
\hline & 2 cuts & $2.52 \mathrm{e}$ & $2.28 \mathrm{c}$ & $2.17 \mathrm{~b}$ & $1.91 \mathrm{a}$ & $2.22 \mathrm{~A}$ \\
\hline & mean & $2.48 \mathrm{C}$ & $2.25 \mathrm{~B}$ & $2.21 \mathrm{~B}$ & $1.95 \mathrm{~A}$ & \\
\hline \multirow{3}{*}{$\begin{array}{l}\text { Total acidity } \\
(\mathrm{g} / 100)\end{array}$} & 1 cut-control & $1.42 \mathrm{~d}$ & $1.17 \mathrm{~b}$ & $1.33 \mathrm{c}$ & $1.21 b$ & $1.28 \mathrm{~A}$ \\
\hline & 2 cuts & $1.37 \mathrm{~cd}$ & $1.04 \mathrm{a}$ & $1.38 \mathrm{~cd}$ & $1.18 \mathrm{~b}$ & $1.24 \mathrm{~A}$ \\
\hline & mean & $1.40 \mathrm{C}$ & $1.11 \mathrm{~A}$ & $1.36 \mathrm{BC}$ & $1.20 \mathrm{AB}$ & \\
\hline \multirow{3}{*}{$\begin{array}{l}L \text {-ascorbic acid } \\
(\mathrm{mg} / 1000)\end{array}$} & 1 cut-control & $70 \mathrm{~d}$ & $64 \mathrm{~cd}$ & $58 \mathrm{bc}$ & $41 \mathrm{a}$ & $58 \mathrm{~A}$ \\
\hline & 2 cuts & $62 \mathrm{bc}$ & $56 \mathrm{bc}$ & $51 b$ & $43 a$ & $53 \mathrm{~A}$ \\
\hline & mean & $66 \mathrm{C}$ & $60 \mathrm{BC}$ & $54 \mathrm{~B}$ & $42 \mathrm{~A}$ & \\
\hline \multirow{3}{*}{$\begin{array}{c}\beta \text {-carotene - } \\
\text { provitamin A (mg/100 g) }\end{array}$} & 1 cut-control & $0.17 \mathrm{a}$ & $0.32 \mathrm{c}$ & $0.20 \mathrm{~b}$ & $0.37 d$ & $0.27 \mathrm{~A}$ \\
\hline & 2 cuts & $0.16 \mathrm{a}$ & $0.34 c$ & $0.22 b$ & $0.41 \mathrm{e}$ & $0.28 \mathrm{~A}$ \\
\hline & mean & $0.17 \mathrm{~A}$ & $0.33 C$ & $0.21 \mathrm{~B}$ & $0.39 \mathrm{D}$ & \\
\hline
\end{tabular}


Table 5. Cont.

\begin{tabular}{|c|c|c|c|c|c|c|}
\hline \multirow{2}{*}{ Compounds } & \multicolumn{6}{|c|}{ Cultivar } \\
\hline & Summer Cuts & Sientiabrskaja & Genewa & Issai & Ken's Red & Mean \\
\hline \multirow{3}{*}{$\begin{array}{c}\text { DPPH• } \\
(\mu \mathrm{mol} \mathrm{T} / \mathrm{g})\end{array}$} & 1 cut-control & $17.7 \mathrm{c}$ & $14.5 \mathrm{~b}$ & 21.3 & $12.5 a$ & $16.5 \mathrm{~A}$ \\
\hline & 2 cuts & $17.5 \mathrm{c}$ & $12.8 \mathrm{a}$ & $21.6 \mathrm{dd}$ & $11.3 a$ & $15.8 \mathrm{~A}$ \\
\hline & mean & $17.6 \mathrm{~B}$ & $13.7 \mathrm{~A}$ & $21.5 \mathrm{C}$ & $11.9 \mathrm{~A}$ & \\
\hline \multirow{3}{*}{$\begin{array}{c}\text { ABTS•+ } \\
(\mu \mathrm{mol} \mathrm{T} / \mathrm{g})\end{array}$} & 1 cut-control & $32.5 b$ & 42.5 & $35.7 c$ & $28.9 a$ & $34.9 \mathrm{~A}$ \\
\hline & 2 cuts & $33.9 \mathrm{~b}$ & 38.6 de & $32.4 \mathrm{~b}$ & $28.0 \mathrm{a}$ & $33.2 \mathrm{~A}$ \\
\hline & mean & $33.2 \mathrm{~B}$ & $40.6 \mathrm{C}$ & $34.1 \mathrm{~B}$ & $28.5 \mathrm{~A}$ & \\
\hline \multirow{3}{*}{$\begin{array}{c}\text { FRAP } \\
(\mu \mathrm{mol} / \mathrm{T} \mathrm{g})\end{array}$} & 1 cut-control & $23.6 \mathrm{~d}$ & $17.4 \mathrm{~b}$ & $21.5 c$ & $13.6 \mathrm{a}$ & $19.0 \mathrm{~A}$ \\
\hline & 2 cuts & $21.1 c$ & $14.6 \mathrm{a}$ & $21.3 c$ & $14.4 \mathrm{a}$ & $17.9 \mathrm{~A}$ \\
\hline & mean & $22.4 \mathrm{~B}$ & $16.0 \mathrm{~A}$ & $21.4 \mathrm{~B}$ & $14.0 \mathrm{~A}$ & \\
\hline \multirow{3}{*}{$\begin{array}{c}\mathrm{NO}_{3} \\
(\mathrm{mg} / 1000 \mathrm{~g})\end{array}$} & 1 cut-control & $45.4 \mathrm{e}$ & $31.7 \mathrm{c}$ & $27.5 b c$ & $22.6 a$ & $31.8 \mathrm{~A}$ \\
\hline & 2 cuts & $57.7 \mathrm{f}$ & $40.8 \mathrm{~d}$ & $20.9 a$ & $24.2 \mathrm{ab}$ & 35.9B \\
\hline & mean & $51.6 \mathrm{C}$ & 36.3B & $24.2 \mathrm{~A}$ & $23.4 \mathrm{~A}$ & \\
\hline
\end{tabular}

* Means followed by the same letter do not differ significantly at $p=0.05$ according to Tukey multiple range; lower-case letters indicate interaction and capital letters the main factors.

\subsection{Basic Physical and Chemical Properties of Actinidia Fruits}

Additional (light) summer pruning resulted in positive changes in kiwi fruit quality. It was observed that SSC, DM and pectin content increased in the fruit. In addition, fruit acidity and $L$-ascorbic acid content decreased (Table 5). In many cases these differences are insignificant, so only a trend can be indicated. The polyphenol profile also changedthe amount of phenolic acid and flavan-3 ols decreased, while the level of anthocyanins increased. The increase in SSC and decrease in acidity and flavan-3-ols (tannins) has a positive effect on the taste of the fruit-in this case the cutting improved the quality. Additional summer pruning also increased the antioxidant capacity of kiwi fruit. Unfortunately, the content of harmful $\mathrm{NO}_{3}$ increased as well. However, kiwi fruit can be considered safe for human consumption. They do not accumulate nitrates like vegetables. The permissible level in products for children should not exceed $200 \mathrm{mg} / 1000 \mathrm{~g}$.

The study also showed a big difference in the content of analysed compounds and antioxidant capacity between cultivars. It was observed that higher antioxidant activity (determined DPPH•, ABTS•+ and FRAP) was found in fruits, which had in their composition anthocyanins-red cultivars Issai and Ken's Red. However, 'Sientiabrskaja' fruits with the highest amount of polyphenols and $L$-ascorbic acid had lower antioxidant activity. According to the ABTS•+ method, the Geneva cultivar had the lowest free radical binding capacity, as much as $40.6 \mu \mathrm{mol} \mathrm{T} / \mathrm{g}$ FW. Wojdyło et al. [40] obtained results of 4.37 $\mathrm{mmol} / 100 \mathrm{~g}$ DW for the same cultivar. Research by Zuo et al. [7] indicates that Actinidia kolomikta has stronger antioxidant activity than A. arguta or A. chinensis.

Leontowicz et al. [14] obtained similar results of percentage SSC content in fruit at $11.8 \%$ to $15.8 \%$. Many authors indicate high vitamin C content in Actinidia fruit $[1,3,5,14]$. In this study, the $L$-ascorbic acid content was found to range from $41 \mathrm{mg} / 1000 \mathrm{~g}$ for the Ken's Red cultivar to $70 \mathrm{mg} / 1000 \mathrm{~g}$ for the Sientiabrskaja cultivar after the first cutting. According to Nishiyama et al. [1], the consumption of 5-6 medium-sized mini kiwi fruits is re-quired to meet the daily vitamin $C$ content requirement for an adult. The Sientiabrskaja cultivar also had the highest total acid content. Leontowicz et al. [14] obtained results of total acid content ranging from $1.15 \%$ to $1.59 \%$, which allows them to be considered similar to our research results (Table 5). Pectins are responsible for proper peristalsis, so their content should be high. The cultivar Ken's Red contained definitely the least of them. The low pectin content for 'Ken's Red' was confirmed by [40]. The pectin content for the Actinidia that they tested ranged from $2.17 \%$ to $3.3 \%$, which was not far different from the results of the present experiment, where results ranging from $1.91 \%$ to $2.52 \%$ were obtained. 


\subsection{Polyphenolic Compounds of Actinidia Fruits}

Twenty-four different polyphenols belonging to four subclasses-anthocyanins, phenolic acids, flavonols, and flavan-3-ols-were identified. Additional shoot pruning affected the amounts of polyphenols determined. Thirteen showed a difference in content depending on the number of shoot cuts. Anthocyanins belong to phenolic compounds that contribute to the red, blue or purple colour of many fruits and are well known for their antioxidant activity [40]. Most kiwi fruit cultivars are characterized by the green or yellow color of the flesh of the ripe fruit. Some kiwi species and cultivars (e.g., A. melanandra and $A$. arguta or their hybrids) also have small amounts of red pigment-anthocyanins, varying in intensity and distribution in the fruit $[3,41]$. The whole fruit is not necessarily red in color, and sometimes a red blush appears on the exposed fruit surfaces [41], as in the case of the Actinidia arguta cultivar named Geneva. The concentration of anthocyanins and their composition in fruit depend on environmental factors, postharvest processing and analytical methods $[42,43]$. The only anthocyanin aglycones detected so far in Actinidia fruits are cyanidin and delphinidin.

Fruit coloring influenced the number of anthocyanins in the fruit. Among the tested Actinidia cultivars, three cyanidins were found: cyanidin 3-O-sambubioside, cyanidinhexoside and cyanidin-pentoside. The cultivar Ken's Red had by far the most anthocyanins, and all 3 forms were present in it, as in the cultivar Geneva. The main anthocyanin in Ken's Red cultivar is cyanidin 3-O-sambubioside, as confirmed by Wojdyło et al. [40]. Only cyanidin 3-O-pentoside was identified in the fruits of the Sientiabrskaja cultivar, and only cyanidin 3-O-hexoside was identified in Issai. Additionally, according to Wojdyło et al. [40], no cyanidin 3-O-sambubioside was found in the Issai, and the Geneva cultivar had a lower value of this compound $-0.7 \mathrm{mg} / 100 \mathrm{~g}$ DW.

Significant differences in the content of phenolic acids in the tested cultivars of Actinidia fruit were observed. Eight phenolic acids were found in the studied Actinidia fruits. The number of cuts had a statistically significant effect on four of the studied acids. The highest number of phenolic acids was found in the fruits of the cv. Sientiabrskaja (Table 6, Figure 1). The dominant acid among the examined was caffeoyl-O-hexoside $\operatorname{Tr} 2$. The highest value of this compound $(7.47 \mathrm{mg} / 100 \mathrm{~g})$ was found in the cultivar Sientiabrskaja after the first cutting. This value was almost $99 \%$ higher than that in the cultivar Ken's Red after the first cut. Wojdyło et al. [40] obtained very similar cryptochlorogenic acid values for the Issai cultivar. However, there were large differences in the cultivar Ken's Red. Wojdyło et al. [40] determined this acid at a level of $6.3 \mathrm{mg} / 100 \mathrm{~g}$, while in our study, the level in the fruit was $0.03 \mathrm{mg} / 100 \mathrm{~g}$. In addition, Wojdyło et al. [40] did not report the existence of this acid in the fruit of 'Geneva', while, in our study, it was at a level of 0.6 $\mathrm{mg} / 100 \mathrm{~g}$.

Nine flavonols were found. The highest contents of five of them were found in 'Ken's Red' fruit. The number of cuts affected the values of five of the studied flavonols. The first cutting increased the content of rutin, kaempferol 3-O-rutinoside and kaempferol 3-Oglucoside. After the second cut, the contents of quercetin 3-O-galactoside and kaempferol 3$O$-glucorhamnoside decreased. The largest differences occurred in the content of quercetin 3-O-galactoside. The amount of this compound after the first cut in the Issai cultivar was $99 \%$ higher than that for the Ken's Red cultivar after the second cut.

Of the identified flavone-3-ols, catechins were the most numerous, especially in 'Sientiabrskaja' fruit after the first cut- $18.2 \mathrm{mg} / 100 \mathrm{~g}$. The second cut caused a decrease in the content of compounds from this group (Figure 1). The cultivar Sientiabrskaja contained the highest amount of polyphenolic compounds $-42.1 \mathrm{mg} / 100 \mathrm{~g}$. The cultivars Issai, Geneva and Ken's Red had $38.4 \%, 33.1 \%$ and $13.7 \%$ fewer polyphenols, respectively. Catechin had the highest amount in this group of compounds, with an average content of 19.5-39.7\%. Analyzing the content of polyphenols for individual cultivars, it can be concluded that in the three cultivars, there was a decrease in their content after the second cut. 


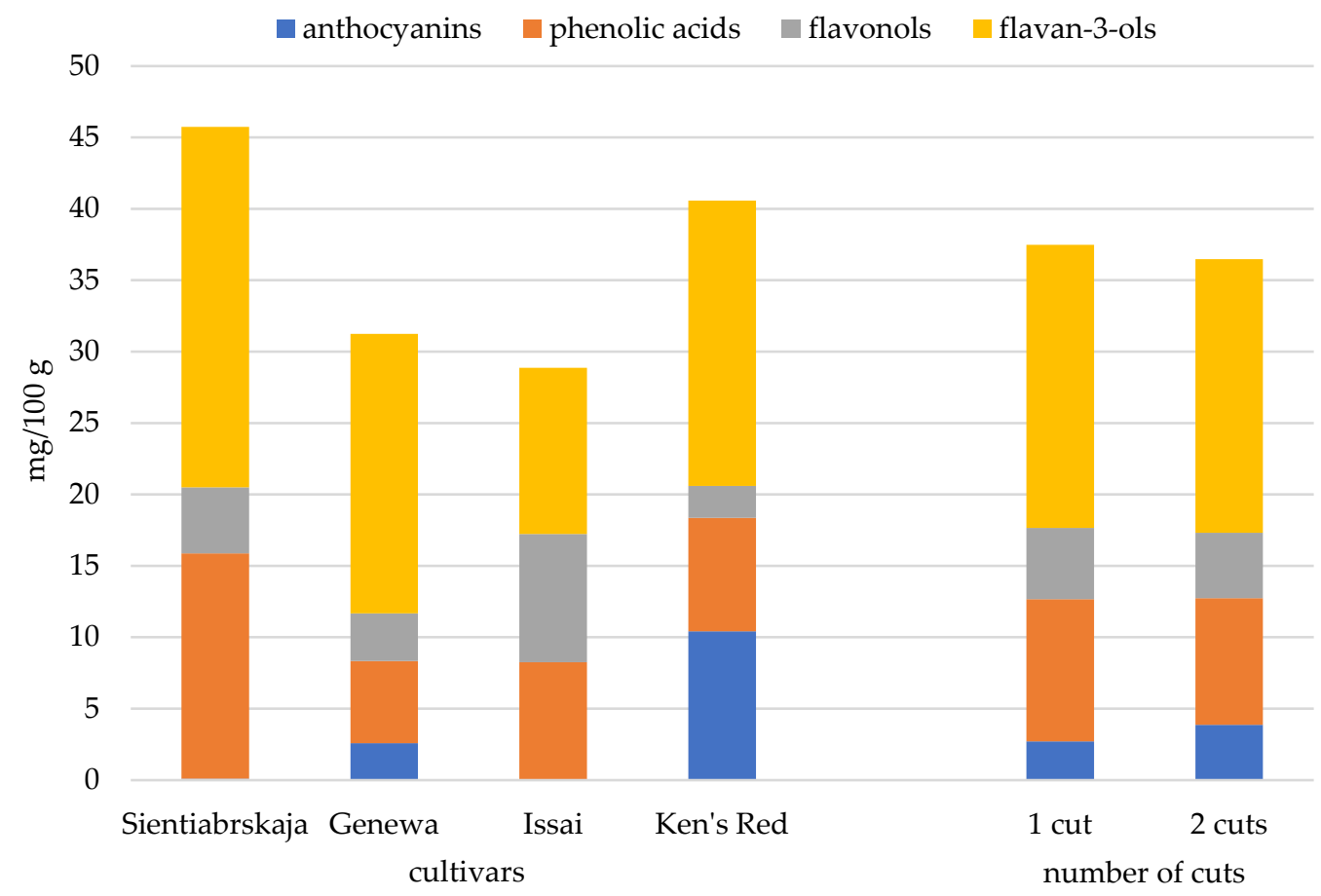

Figure 1. Sum of polyphenols in the studied cultivars of Actinidia.

Table 6. Polyphenols derivative contents in Actinidia fruits.

\begin{tabular}{|c|c|c|c|c|c|c|}
\hline \multirow{2}{*}{$\begin{array}{l}\text { Compounds } \\
\text { (mg/100 g) }\end{array}$} & \multicolumn{6}{|c|}{ Cultivar } \\
\hline & Summer Cuts & Sientiabrskaja & Genewa & Issai & Ken's Red & Mean \\
\hline \multirow{3}{*}{ Cyanidin 3-O-sambubioside } & 1 cut-control & n.d. & $1.93 a *$ & n.d. & $7.81 \mathrm{c}$ & $2.44 \mathrm{~A}$ \\
\hline & 2 cuts & n.d. & $2.44 \mathrm{~b}$ & n.d. & $11.78 \mathrm{~d}$ & $3.56 \mathrm{~B}$ \\
\hline & mean & n.d. & $2.19 \mathrm{~A}$ & n.d. & $9.80 \mathrm{~B}$ & \\
\hline \multirow{3}{*}{ Cyanidin 3-O-hexoside } & 1 cut-control & n.d. & $0.14 b$ & $0.05 \mathrm{a}$ & $0.19 \mathrm{c}$ & $0.10 \mathrm{~A}$ \\
\hline & 2 cuts & n.d. & $0.17 \mathrm{bc}$ & $0.02 \mathrm{a}$ & $0.20 c$ & $0.10 \mathrm{~A}$ \\
\hline & mean & n.d. & $0.16 \mathrm{~B}$ & $0.04 \mathrm{~A}$ & $0.20 \mathrm{C}$ & \\
\hline \multirow{3}{*}{ Cyanidin 3-O-pentoside } & 1 cut-control & $0.09 a$ & $0.22 b$ & n.d. & $0.35 \mathrm{~d}$ & $0.17 \mathrm{~A}$ \\
\hline & 2 cuts & $0.11 \mathrm{a}$ & $0.25 c$ & n.d. & $0.48 \mathrm{e}$ & $0.21 \mathrm{~A}$ \\
\hline & mean & $0.10 \mathrm{~A}$ & $0.24 \mathrm{~B}$ & n.d. & $0.42 \mathrm{C}$ & \\
\hline \multirow{3}{*}{ Caffeoyl-O-hexoside } & 1 cut-control & $4.44 \mathrm{e}$ & $0.41 b$ & $0.05 a$ & $2.62 c$ & $1.88 \mathrm{~A}$ \\
\hline & 2 cuts & $3.58 \mathrm{~d}$ & $0.31 b$ & $0.08 \mathrm{a}$ & $3.85 \mathrm{~d}$ & $1.96 \mathrm{~A}$ \\
\hline & mean & $4.01 \mathrm{D}$ & $0.36 \mathrm{~B}$ & $0.07 \mathrm{~A}$ & $3.24 \mathrm{C}$ & \\
\hline \multirow{3}{*}{ Caffeoyl-O-hexoside } & 1 cut-control & $1.70 \mathrm{~b}$ & $1.06 \mathrm{a}$ & $5.25 \mathrm{e}$ & $2.62 \mathrm{c}$ & $2.66 \mathrm{~B}$ \\
\hline & 2 cuts & $1.42 b$ & $0.89 a$ & $4.93 \mathrm{~d}$ & $2.36 c$ & $2.40 \mathrm{~A}$ \\
\hline & mean & $1.56 \mathrm{~B}$ & $0.98 \mathrm{~A}$ & $5.09 \mathrm{D}$ & $2.49 \mathrm{C}$ & \\
\hline \multirow{3}{*}{ Caffeoyl-O-hexoside } & 1 cut-control & $2.47 \mathrm{de}$ & $1.81 \mathrm{c}$ & $2.56 \mathrm{e}$ & $1.73 b c$ & $2.14 \mathrm{~B}$ \\
\hline & 2 cuts & 2.30de & $1.06 a$ & $2.22 d$ & $1.58 \mathrm{~b}$ & $1.79 \mathrm{~A}$ \\
\hline & mean & $2.39 \mathrm{~B}$ & $1.44 \mathrm{~A}$ & $2.39 \mathrm{~B}$ & $1.66 \mathrm{~A}$ & \\
\hline \multirow{3}{*}{ Caffeoyl-malic acid } & 1 cut-control & $7.47 \mathrm{f}$ & $2.18 \mathrm{~d}$ & $0.31 b$ & $0.10 \mathrm{a}$ & $2.52 B$ \\
\hline & 2 cuts & $5.82 \mathrm{e}$ & $1.69 c$ & $0.28 \mathrm{~b}$ & $0.12 \mathrm{a}$ & $1.98 \mathrm{~A}$ \\
\hline & mean & $6.65 \mathrm{D}$ & $1.94 \mathrm{C}$ & $0.30 \mathrm{~B}$ & $0.11 \mathrm{~A}$ & \\
\hline \multirow{3}{*}{ Chlorogenic acid } & 1 cut-control & $0.42 \mathrm{e}$ & $0.36 \mathrm{~d}$ & $0.17 \mathrm{a}$ & $0.27 \mathrm{c}$ & $0.31 \mathrm{~B}$ \\
\hline & 2 cuts & $0.35 \mathrm{~d}$ & $0.22 b$ & $0.14 \mathrm{a}$ & $0.30 \mathrm{c}$ & $0.25 \mathrm{~A}$ \\
\hline & mean & $0.39 \mathrm{C}$ & $0.29 \mathrm{~B}$ & $0.16 \mathrm{~A}$ & $0.29 \mathrm{~B}$ & \\
\hline \multirow{3}{*}{ Dimethyl caffeic acid hexoside } & 1 cut-control & $0.22 \mathrm{c}$ & $0.08 b$ & $0.06 \mathrm{ab}$ & $0.06 \mathrm{ab}$ & $0.11 \mathrm{~A}$ \\
\hline & 2 cuts & $0.25 \mathrm{~d}$ & $0.06 \mathrm{ab}$ & $0.05 \mathrm{a}$ & $0.08 \mathrm{~b}$ & $0.11 \mathrm{~A}$ \\
\hline & mean & $0.24 \mathrm{~B}$ & $0.07 \mathrm{~A}$ & $0.06 \mathrm{~A}$ & $0.07 \mathrm{~A}$ & \\
\hline
\end{tabular}


Table 6. Cont.

\begin{tabular}{|c|c|c|c|c|c|c|}
\hline \multirow{2}{*}{$\begin{array}{l}\text { Compounds } \\
\text { (mg/100 g) }\end{array}$} & \multicolumn{6}{|c|}{ Cultivar } \\
\hline & Summer Cuts & Sientiabrskaja & Genewa & Issai & Ken's Red & Mean \\
\hline \multirow{3}{*}{ Feruoylglucoside } & 1 cut-control & $0.11 \mathrm{c}$ & $0.04 \mathrm{ab}$ & $0.02 \mathrm{a}$ & $0.05 b$ & $0.06 \mathrm{~A}$ \\
\hline & 2 cuts & $0.13 c$ & $0.06 \mathrm{~b}$ & $0.03 a$ & $0.04 \mathrm{ab}$ & $0.07 \mathrm{~A}$ \\
\hline & mean & $0.12 \mathrm{~B}$ & $0.05 \mathrm{~A}$ & $0.03 \mathrm{~A}$ & $0.05 \mathrm{~A}$ & \\
\hline \multirow{3}{*}{ Cryptochlorogenic acid } & 1 cut-control & $0.39 d$ & $0.60 c$ & $0.10 \mathrm{~b}$ & $0.03 a$ & $0.28 \mathrm{~A}$ \\
\hline & 2 cuts & $0.42 \mathrm{~d}$ & $0.63 c$ & $0.12 b$ & $0.02 \mathrm{a}$ & $0.30 \mathrm{~A}$ \\
\hline & mean & $0.41 \mathrm{C}$ & $0.62 \mathrm{D}$ & $0.11 \mathrm{~B}$ & $0.03 \mathrm{~A}$ & \\
\hline \multirow{3}{*}{ Rutin } & 1 cut-control & $0.39 c$ & $0.15 b$ & $0.71 d$ & $0.01 \mathrm{a}$ & $0.32 \mathrm{~A}$ \\
\hline & 2 cuts & $0.42 \mathrm{c}$ & $0.18 b$ & $1.55 \mathrm{e}$ & $0.03 \mathrm{a}$ & $0.55 \mathrm{~B}$ \\
\hline & mean & $0.41 \mathrm{C}$ & $0.17 \mathrm{~B}$ & 1.13D & $0.02 \mathrm{~A}$ & \\
\hline \multirow{3}{*}{ Quercetin 3-O-hexoso-rhamnoside } & 1 cut-control & $1.83 \mathrm{c}$ & $1.84 \mathrm{c}$ & $2.16 \mathrm{~d}$ & $0.98 b$ & $1.70 \mathrm{~A}$ \\
\hline & 2 cuts & $2.04 \mathrm{~d}$ & $1.78 \mathrm{c}$ & $2.55 \mathrm{e}$ & $0.77 \mathrm{a}$ & $1.79 \mathrm{~A}$ \\
\hline & mean & $1.94 \mathrm{~B}$ & $1.81 \mathrm{~B}$ & $2.36 \mathrm{C}$ & $0.88 \mathrm{~A}$ & \\
\hline \multirow{3}{*}{ Quecetin 3-O-galactoside } & 1 cut-control & $0.59 \mathrm{~d}$ & $0.53 \mathrm{~cd}$ & $3.22 \mathrm{f}$ & $0.04 \mathrm{a}$ & $1.10 \mathrm{~B}$ \\
\hline & 2 cuts & $0.45 c$ & $0.28 b$ & $1.89 \mathrm{e}$ & $0.03 \mathrm{a}$ & $0.66 \mathrm{~A}$ \\
\hline & mean & $0.52 \mathrm{~B}$ & $0.41 \mathrm{~B}$ & $2.56 \mathrm{C}$ & $0.04 \mathrm{~A}$ & \\
\hline \multirow{3}{*}{ Quecetin 3-O-glucoside } & 1 cut-control & $0.06 \mathrm{ab}$ & $0.03 a$ & $1.68 \mathrm{e}$ & $0.05 \mathrm{a}$ & $0.46 \mathrm{~A}$ \\
\hline & 2 cuts & $0.05 \mathrm{a}$ & $0.12 b$ & $1.23 \mathrm{~d}$ & $0.38 \mathrm{c}$ & $0.45 \mathrm{~A}$ \\
\hline & mean & $0.06 \mathrm{~A}$ & $0.08 \mathrm{~A}$ & $1.46 \mathrm{C}$ & $0.22 \mathrm{~B}$ & \\
\hline \multirow{3}{*}{ Kaempferol 3-O-rutinoside } & 1 cut-control & $0.14 \mathrm{~d}$ & $0.09 \mathrm{bc}$ & $0.08 \mathrm{~b}$ & $0.04 a$ & $0.09 \mathrm{~A}$ \\
\hline & 2 cuts & $0.07 \mathrm{ab}$ & $0.05 \mathrm{a}$ & $0.25 \mathrm{e}$ & $0.12 \mathrm{~cd}$ & $0.12 \mathrm{~B}$ \\
\hline & mean & $0.11 \mathrm{~B}$ & $0.07 \mathrm{~A}$ & $0.17 \mathrm{C}$ & $0.08 \mathrm{AB}$ & \\
\hline \multirow{3}{*}{ Kaempferol 3-O-glucorhamnoside } & 1 cut-control & $1.23 \mathrm{e}$ & $0.70 \mathrm{c}$ & $1.03 \mathrm{~d}$ & $0.35 \mathrm{a}$ & $0.83 \mathrm{~B}$ \\
\hline & 2 cuts & $0.58 b$ & $0.32 \mathrm{a}$ & $0.47 \mathrm{~b}$ & $0.51 b$ & $0.47 \mathrm{~A}$ \\
\hline & mean & $0.91 \mathrm{C}$ & $0.51 \mathrm{~A}$ & $0.75 B$ & $0.43 \mathrm{~A}$ & \\
\hline \multirow{3}{*}{ Kaempferol 3-O-galactoside } & 1 cut-control & $0.52 \mathrm{e}$ & $0.15 b c$ & $0.34 \mathrm{~d}$ & $0.10 \mathrm{a}$ & $0.28 \mathrm{~A}$ \\
\hline & 2 cuts & $0.37 \mathrm{~d}$ & $0.11 \mathrm{ab}$ & $0.19 \mathrm{c}$ & $0.38 \mathrm{~d}$ & $0.26 \mathrm{~A}$ \\
\hline & mean & $0.45 \mathrm{C}$ & $0.13 \mathrm{~A}$ & $0.27 \mathrm{~B}$ & $0.24 \mathrm{AB}$ & \\
\hline \multirow{3}{*}{ Kaempferol 3-O-glucoside } & 1 cut-control & $0.17 \mathrm{bc}$ & $0.18 b c$ & $0.19 \mathrm{c}$ & $0.16 b$ & $0.18 \mathrm{~A}$ \\
\hline & 2 cuts & $0.10 \mathrm{a}$ & $0.12 \mathrm{a}$ & $0.34 \mathrm{~d}$ & $0.48 \mathrm{e}$ & $0.26 \mathrm{~B}$ \\
\hline & mean & $0.14 \mathrm{~A}$ & $0.15 \mathrm{~A}$ & $0.27 \mathrm{~B}$ & $0.32 B$ & \\
\hline \multirow{3}{*}{ Kaempferol 3,7-dirhamnoside } & 1 cut-control & $0.06 \mathrm{~b}$ & n.d. & $0.01 \mathrm{a}$ & n.d. & $0.02 \mathrm{~A}$ \\
\hline & 2 cuts & $0.12 \mathrm{c}$ & n.d. & n.d. & n.d. & $0.03 \mathrm{~A}$ \\
\hline & mean & $0.09 \mathrm{~B}$ & n.d. & $0.01 \mathrm{~A}$ & n.d. & \\
\hline \multirow{3}{*}{ Proanthocyanidin dimer B2 } & 1 cut-control & $4.13 \mathrm{~d}$ & $2.77 \mathrm{~b}$ & $3.05 b$ & $5.12 \mathrm{e}$ & 3.77B \\
\hline & 2 cuts & $3.67 \mathrm{c}$ & $1.89 \mathrm{a}$ & $2.28 \mathrm{a}$ & $5.89 \mathrm{f}$ & $3.43 \mathrm{~A}$ \\
\hline & mean & $2.33 \mathrm{~A}$ & $2.67 \mathrm{~B}$ & $2.33 \mathrm{~A}$ & $5.51 \mathrm{C}$ & \\
\hline \multirow{3}{*}{ Proanthocyanidin dimer B2 } & 1 cut-control & $0.83 b$ & $2.45 \mathrm{e}$ & $1.22 \mathrm{~d}$ & $0.58 \mathrm{a}$ & $1.27 \mathrm{~A}$ \\
\hline & 2 cuts & $1.16 \mathrm{~d}$ & $3.89 \mathrm{f}$ & $0.87 \mathrm{bc}$ & $0.99 \mathrm{~cd}$ & $1.73 \mathrm{~B}$ \\
\hline & mean & $1.00 \mathrm{~B}$ & $3.17 \mathrm{C}$ & $1.05 \mathrm{~B}$ & $0.79 \mathrm{~A}$ & \\
\hline \multirow{3}{*}{$(+)$-Catechin } & 1 cut-control & $18.20 \mathrm{~g}$ & $10.55 \mathrm{~d}$ & $5.86 \mathrm{~b}$ & $8.64 \mathrm{c}$ & $10.81 \mathrm{~A}$ \\
\hline & 2 cuts & $15.33 \mathrm{f}$ & $11.57 \mathrm{e}$ & $4.25 \mathrm{a}$ & $10.35 d$ & $10.38 \mathrm{~A}$ \\
\hline & mean & 16.77D & $11.06 \mathrm{C}$ & $5.06 \mathrm{~A}$ & $9.50 \mathrm{~B}$ & \\
\hline \multirow{3}{*}{ (-)-Epicatechin } & 1 cut-control & $5.38 \mathrm{f}$ & $2.78 b$ & $3.92 \mathrm{c}$ & $3.83 c$ & $3.98 \mathrm{~B}$ \\
\hline & 2 cuts & $4.89 \mathrm{e}$ & $2.55 \mathrm{ab}$ & $2.47 \mathrm{a}$ & $4.52 \mathrm{~d}$ & $3.61 \mathrm{~A}$ \\
\hline & mean & $5.14 \mathrm{D}$ & $2.67 \mathrm{~A}$ & $3.20 \mathrm{~B}$ & $4.18 \mathrm{C}$ & \\
\hline \multirow{3}{*}{ Total } & 1 cut-control & $45.46 \mathrm{~d}$ & $28.27 \mathrm{~b}$ & $28.12 b$ & $31.90 \mathrm{~b}$ & $33.44 \mathrm{~A}$ \\
\hline & 2 cuts & $38.74 \mathrm{c}$ & $28.09 b$ & $23.74 a$ & $40.74 \mathrm{c}$ & $32.83 \mathrm{~A}$ \\
\hline & mean & 42.10D & $28.18 \mathrm{~B}$ & $25.93 \mathrm{~A}$ & $36.32 \mathrm{C}$ & \\
\hline
\end{tabular}

* Means followed by the same letter do not differ significantly at $p=0.05$ according to Tukey multiple range; lower-case letters indicate interaction and capital letters the main factors. 


\section{Conclusions}

Additional (for lighting) summer pruning done during their ripening period improved the quality of mini kiwi fruit. Actinidia fruits are a rich source of mineral compounds and bioactive substances. Fruit quality was influenced by an additional cutting of plants (the second one), performed during their ripening period. After the second pruning of Actinidia shoots, an increase in the content of N, P and K in fruits was observed. This treatment had no effect on the micronutrient content of the fruit. The second shoot pruning had a positive effect on fruit color change. The fruits were darker, especially in the cultivars Geneva and Ken's Red. This is connected with the ripening of fruits and the increase in anthocyanin content. Additional summer pruning caused changes in the polyphenol content the amount of phenolic acid and flavan-3-ols (tannins) decreased, while the level of anthocyanins increased. Decreasing the amount of flavan-3-ols had a positive effect on the flavor of the fruit.

Soluble solid content, dry matter and pectin content also increased in the fruit. The fruit acidity and L-ascorbic acid content also decreased. The increase in SSC content and the decrease in acidity and flavan-3-ols have a positive effect on fruit flavor-in this case. The additional summer pruning also increased the antioxidant capacity of kiwi fruits and had a positive effect on their size.

Author Contributions: Conceptualization, I.O., and M.F.-K.; methodology, M.F.-K., I.O., S.L., M.K.-M., J.W., and R.G.; software, I.O., and S.L.; validation, I.O., S.L., and M.K.-M.; formal analysis, M.F-K., I.O., S.L., M.K.-M., J.W., and R.G.; data curation, I.O.; writing—original draft preparation, M.F-K., I.O., S.L., and M.K.-M.; writing—review and editing, M.K.-M.; visualization, I.O.; supervision, I.O. All authors have read and agreed to the published version of the manuscript.

Funding: This research was funded by the West Pomeranian University of Technology of grants nr 518-07-014-3171-03/18.

Institutional Review Board Statement: Not applicable.

Informed Consent Statement: Not applicable.

Data Availability Statement: Not applicable.

Conflicts of Interest: The authors declare no conflict of interest.

\section{References}

1. Nishiyama, I.; Fukuda, T.; Oota, T. Varietal differences in actinidin concentration and protease activity in the fruit juice of Actinidia arguta and Actinidia rufa. J. Jpn. Soc. Hortic. Sci. 2004, 73, 157-162. [CrossRef]

2. Chesoniene, L.; Daubaras, R.; Viskelis, P. Biochemical composition of berries of some kolomikta kiwi (Actinidia kolomikta) cultivars and detection of harvest maturity. In XI Eucarpia Symposium on Fruit Breeding and Genetics; International Society for Horticultural Science: Angers, France, 2003; Volume 663, pp. 305-308.

3. Latocha, P. The Nutritional and Health Benefits of Kiwiberry (Actinidia arguta)—A Review. Plant Foods Hum. Nutr. 2017, 72, 325-334. [CrossRef]

4. Thaipong, K.; Boonprakob, U.; Crosby, K.; Cisneros-Zevallos, L.; Byrne, D.H. Comparison of ABTS, DPPH•, FRAP, and ORAC assays for estimating antioxidant activity from guava fruit extracts. J. Food Compost. Anal. 2006, 19, 669-675. [CrossRef]

5. Drummond, L. The composition and nutritional value of kiwi fruit. Adv. Food Nutr. Res. 2013, 68, 33-57.

6. Nishiyama, I.; Fukuda, T.; Shimohashi, A.; Oota, T. Sugar and organic acid composition in the fruit juice of different Actinidia varieties. Food. Sci. Technol. Res. 2008, 14, 67-73. [CrossRef]

7. Zuo, L.L.; Wang, Z.Y.; Fan, Z.L.; Tian, S.Q.; Liu, J.R. Evaluation of antioxidant and antiproliferative properties of three Actinidia (Actinidia kolomikta, Actinidia arguta, Actinidia chinensis) extracts in vitro. Int. J. Mol. Sci. 2012, 13, 5506-5518. [CrossRef]

8. Nishiyama, I.; Yamashita, Y.; Yamanaka, M.; Shimohashi, A.; Fukuda, T.; Oota, T. Varietal difference in vitamin C content in the fruit of kiwi fruit and other Actinidia species. J. Agric. Food Chem. 2004, 52, 5472-5475. [CrossRef] [PubMed]

9. Nishiyama, I.; Fukuda, T.; Oota, T. Genotypic differences in chlorophyll, lutein, and $\beta$-carotene contents in the fruits of actinidia species. J. Agric. Food. Chem. 2005, 53, 6403-6407. [CrossRef]

10. Valko, M.; Rhodes, C.; Moncol, J.; Izakovic, M.M.; Mazur, M. Free radicals, metals and antioxidants in oxidative stress-induced cancer. Chem. Biol. Interact. 2006, 160, 1-40. [CrossRef] [PubMed]

11. Du, G.; Li, M.; Ma, F.; Liang, D. Antioxidant capacity and the relationship with polyphenol and vitamin C in Actinidia fruits. Food Chem. 2009, 113, 557-562. [CrossRef] 
12. Muto, Y.; Fujii, J.; Shidoji, Y.; Moriwaki, H.; Kawaguchi, T.; Noda, T. Growth retardation in human cervical dysplasia-derived cell lines by beta-carotene through down-regulation of epidermal growth factor receptor. Am. J. Clin. Nutr. 1995, 62, 1535S-1540S. [CrossRef] [PubMed]

13. Karas, M.; Amir, H.; Fishman, D.; Danilenko, M.; Segal, S.; Nahum, A.; Koifmann, A.; Giat, Y.; Levy, J.; Sharoni, Y. Lycopene interferes with cell cycle progression and insulin-like growth factor i signaling in mammary cancer cells. Nutr. Cancer 2000, 36, 101-111. [CrossRef]

14. Leontowicz, H.; Leontowicz, M.; Latocha, P.; Jesion, I.; Park, Y.S.; Katrich, E.; Barasch, D.; Nemirovski, A.; Gorinstein, S. Bioactivity and nutritional properties of hardy kiwi fruit Actinidia arguta in comparison with Actinidia deliciosa 'Hayward' and Actinidia eriantha 'Bidan'. Food Chem. 2016, 196, 281-291. [CrossRef] [PubMed]

15. Ochmian, I.; Błaszak, M.; Lachowicz, S.; Piwowarczyk, R. The impact of cultivation systems on the nutritional and phytochemical content, and microbiological contamination of highbush blueberry. Sci. Rep. 2020, 10, 16696. [CrossRef]

16. Strik, B.C.; Cahn, H. Growing Kiwi Fruit; Oregon State University Extension Service Publication PNW: Corvallis, OR, USA, 1998; Volume 507, pp. 1-6.

17. Tiyayon, C.; Strik, B. Influence of time ofoverhead shading on yield, fruit quality, and subsequent flowering of hardy kiwi fruit, Actinidia arguta. N. Z. J. Crop Hortic. Sci. 2004, 32, 235-241. [CrossRef]

18. Ochmian, I.; Oszmiański, J.; Lachowicz, S.; Krupa-Małkiewicz, M. Rootstock effect on physico-chemical properties and content of bioactive compounds of four cultivars Cornelian cherry fruits. Sci. Hortic. 2019, 256, 108588. [CrossRef]

19. IUNG Institute of Soil Science and Plant Cultivation. Fertiliser Recommendations Part I-Limits for Estimating Soil Macro- and Microelement Content; Series P. Państwowy Instytut Badawczy w Puławach: Puławy, Poland, 1990; pp. 26-28.

20. Ochmian, I.; Oszmiański, J.; Jaśkiewicz, B.; Szczepanek, M. Soil and high bush blueberry responses to fertilization with urea phosphate. Folia Hortic. 2018, 30, 295-305. [CrossRef]

21. Polish Committee for Standardisation. Fruit and Vegetable Preparations_Sample preparation and Physicochemical Test Methods; PN-EN 12145; Polish Committee for Standardisation: Warszawa, Poland, 2001.

22. Mijowska, K.; Ochmian, I.; Oszmiański, J. Impact of cluster zone leaf removal on grapes cv. regent polyphenol content by the UPLC-PDA/MS method. Molecules 2016, 21, 1688. [CrossRef] [PubMed]

23. Pijanowski, E.; Mrożewski, S.; Horubała, A.; Jarczyk, A. Technology of Fruit and Vegetable Products; PWRiL: Warsaw, Poland, 1973; pp. 137-155.

24. Kruczek, A.; Ochmian, I.; Krupa-Małkiewicz, M.; Lachowicz, S. Comparison of morphological, antidiabetic and antioxidant properties of goji fruits. Acta Univ. Cibiniensis Ser. E Food Technol. 2020, 24, 1-14. [CrossRef]

25. Ochmian, I.; Grajkowski, J.; Smolik, M. Comparison of some morphological features, quality and chemical content of four cultivars of chokeberry fruits (Aronia melanocarpa). Not. Bot. Horti Agrobot. Cluj Napoca 2012, 40, 253-260. [CrossRef]

26. Oszmiański, J.; Lachowicz, S.; Gławdel, E.; Cebulak, T.; Ochmian, I. Determination of photochemical composition and antioxidant capacity of 22 old apple cultivars grown in Poland. Eur. Food Res. Technol. 2018, 244, 647-662. [CrossRef]

27. Arnao, M.B.; Cano, A.; Acosta, M. The hydrophilic and lipophilic contribution to total antioxidant activity. Food Chem. 2001, 73, 239-244. [CrossRef]

28. Akar, Z.; Küçük, M.; Doğan, H. A new colorimetric DPPH• scavenging activity method with no need for a spectrophotometer applied on synthetic and natural antioxidants and medicinal herbs. J. Enzyme Inhib. Med. Chem. 2017, 32, 640-647. [CrossRef]

29. Benzie, I.F.; Devaki, M. The ferric reducing/antioxidant power (FRAP) assay for non-enzymatic antioxidant capacity: Concepts, procedures, limitations and applications. In Measurement of Antioxidant Activity \& Capacity: Recent Trends and Applications; Apak, R., Capanoglu, E., Shahidi, F., Eds.; John Wiley \& Sons Ltd.: Hoboken, NJ, USA, 2018; pp. 77-106.

30. Bieniek, A. Mineral Composition of Fruits of Actinidia Arguta and Actinidia Purpurea and Some of Their Hybrid Cultivars Grown in Northeastern Poland. Pol. J. Environ. Stud. 2012, 21, 1543-1550.

31. Ochmian, I.; Kozos, K. Influence of foliar fertilization with calcium fertilizers on the firmness and chemical composition of two high bush blueberry cultivars. J. Elementol. 2015, 20, 185-201.

32. Nascimento, A.N.; Silvestre, D.M.; de Oliveira Leme, F.; Nomura, C.S.; Naozuka, J. Elemental analysis of goji berries using axially and radially viewed inductively coupled plasma-opical emissin spectometry. Spectometry 2015, 30, 36-41.

33. Regulation EU. No 1169/2011 of the European Parliament and of the Council of 25 October 2011 on the Provision of Food Information to Consumers; No 1169/2011; Official Journal of the European Union: Luxembourg, 2011; Volume 304, pp. 18-63.

34. Sunde, R.A.; Raines, A.M. Selenium regulation of the selenoprotein and nonselenoprotein transcriptomes in rodents. Adv. Nutr. 2011, 2, 138-150. [CrossRef]

35. Ramaekers, V.T.; Calomme, M.; Vanden Berghe, D. Selenium deficiency triggering intractable seizures. Neuropediatrics 1994, 25, 217-223. [CrossRef]

36. Falandysz, J.; Lipka, K. Selenium in mushrooms. Roczn. Państw. Zakt. Hig. 2006, 52, 217-233.

37. Fairweather-Tait, S.J.; Collings, R.; Hurst, R. Selenium bioavailability: Current knowledge and future research requirements. Am. J. Clin. Nutr. 2010, 91, 1484S-1491S. [CrossRef]

38. Dougnon, T.V.; Bankolé, H.S.; Johnson, R.C.; Klotoé, J.R.; Dougnon, G.; Gbaguidi, F.; Rhin, B.H. Phytochemical screening, nutritional and toxicological analyses of leaves and fruits of Solanum macrocarpon Linn (Solanaceae) in Cotonou (Benin). Food Nutri. Sci. 2012, 3, 1595-1603. [CrossRef] 
39. Reports of the Scientific Committee for Food (SCF). Nutrient and energy intakes for the European Community; Thirty-First Series; Office for Official Publications of the European Communities: Brussels, Belgium; Luxembourg, 1993.

40. Wojdyło, A.; Nowicka, P.; Oszmiański, J.; Golis, T. Phytochemical compounds and biological effects of Actinidia fruits. J. Funct. Foods. 2017, 30, 194-202. [CrossRef]

41. Montefiori, M.; Comeskey, D.J.; Wohlers, M.; McGhie, T.K. Characterization and quantification of anthocyanins in red kiwi fruit (Actinidia spp.). J. Agric. Food Chem. 2009, 57, 6856-6861. [CrossRef] [PubMed]

42. Wojdyło, A.; Jáuregui, P.; Carbonell-Barrachina, A.A.; Oszmiański, J.; Golis, T. Variability of phytochemical properties and content of bioactive compounds in Lonicera caerulea L. var. kamtschatica berries. J. Agric. Food Chem. 2013, 61, 12072-12084. [CrossRef] [PubMed]

43. Ochmian, I.; Kubus, M.; Dobrowolska, A. Description of plants and assessment of chemical properties of three species from the Amelanchier genus. Dendrobiology 2013, 70, 59-64. [CrossRef] 